\title{
Genetic position of Hungarian Grey among European cattle and identification of breed-specific markers
}

\author{
A. Zsolnai ${ }^{1 \dagger} \odot$, Á. Maróti-Agóts² ${ }^{2}$ A. Kovács ${ }^{1}$, A. V. Bâlteanu ${ }^{3}$, E. Kaltenecker ${ }^{4}$ and I. Anton ${ }^{1}$ \\ ${ }^{1}$ Laboratory of Genetics, NAIK-Research Institute for Animal Breeding, Nutrition and Meat Science, Gesztenyés u. 1., 2053 Herceghalom, Hungary; ${ }^{2}$ Department of Animal \\ Breeding and Genetics, University of Veterinary Medicine, István u. 2, 1078, Budapest, Hungary; ${ }^{3}$ Laboratory of Genomics, Biodiversity, Animal Breeding and Molecular \\ Pathology, Institute of Life Sciences, University of Agricultural Sciences and Veterinary Medicine, Calea Mănăştur 3-5, 400372 Cluj-Napoca, Romania; ${ }^{4}$ Association of \\ Hungarian Grey Cattle Breeders, Löportár u. 16., 1134 Budapest, Hungary
}

(Received 11 November 2019; Accepted 3 March 2020; First published online 6 April 2020)

\begin{abstract}
Hungarian Grey is an indigenous cattle breed that is one of the national symbols of Hungary. However, genetic description of the Hungarian Grey cattle has not yet been conducted based on whole-genome screening. Using the GeneSeek high-density Bovine SNP (single nucleotide polymorphism) $150 \mathrm{~K}$ BeadChip, we sampled the genome of 36 Hungarian Grey, 12 Maremmana, 13 Hungarian Fleckvieh and 5 Holstein-Friesian cattle for population studies and used data of 139 other cattle from an additional dataset created on European cattle breeds (Upadhyay et al. 2017. Heredity 118, 169-176). The performance of a multidimensional scaling plot showed that Hungarian Grey clustered independently from other European cattle. The number and total length of runs of homozygosity $(\mathbf{R O H})$ is similar or slightly below the value of other European cattle; $\mathrm{F}_{\mathrm{ROH}}$ Coefficients (proportion of the autosomal genome covered by ROH) are similar to Maremmana and Maronesa. The frequency of ROH does not show increased values as it can be noticed in Heck and Maltese. These results indicate that the Hungarian Grey cattle have been successfully maintained avoiding negative genetic effects, and reflect the uniqueness among European cattle. The identification of breed-specific loci has been aimed at differentiating Hungarian Grey $(\mathrm{n}=136$ in this case) from other cattle breeds $(\mathrm{n}=169)$. Ten loci $\left(-\log _{10} \mathrm{P}>5\right)$ were identified as markers capable for differentiation of Hungarian Grey. These markers are located on chromosomes 6, 14, 15, 16, 20 and 24.
\end{abstract}

Keywords: population, admixture, homozygosity, polymorphism, differentiation

\section{Implications}

Genetic characterisation via whole-genome scan gives feedback to the breeders about the status of this breed. The analysis provides markers to support competitiveness of the Hungarian Grey breed.

\section{Introduction}

There are several theories regarding the origins of the Hungarian Grey cattle. One of the theories is that Hungarian Grey arrived in the Pannonian Basin with the 9th-century Hungarian immigration from the east. Another theory leans towards the opinion that domestication of Hungarian Grey took place in the Pannonian Basin, during the reign of House of Árpád Kings, from aurochs (Bos Primigenius), the ancestors of domestic cattle (Bartosiewicz, 1996). The first written document referring to the Hungarian Grey cattle as 'magnus cornuotes boves Hungaricos' dates back to the 16th century (Bartosiewicz,

† E-mail: attila.zsolnai@gmail.com
1997). In former times (10th to 13th centuries), most cattle in Hungary had been small, brachyceros-type animals (Bartosiewicz, 1997). Written evidence for westward export (Germany, Italy, Moravia) of Hungarian cattle is known from the 14th century (Miskulin, 1905). The long-horned larger cattle have been introduced to the Balkan countries and the Carpathian Basin by the Turkish Ottoman Empire during the 16th- to 18th-century campaigns (Bartosiewicz, 1996 and 1997).

The breed was used as a draught animal, but it has been bred also for its beef quality. Phenotypic traits of this breed, such as strong pigmentation, long dark eyelashes and welldeveloped dewlap, show similarities to ancient North African pictures from Egypt and the Sahara region. The Turkish army occupied the Near-East and the North African region long before the European invasion, so it seems that cattle of southern origin have been introduced to our continent later (16 to 18 th centuries).

In 1884 , the overwhelming majority (78\%) of the 4.9 million cattle in Hungary were registered as Hungarian Grey, and half of the 6.7 million still belonged to this breed in 1900 (Mattesz, 1927; Tormay, 1901). 
After World War I, when Hungary lost about $72 \%$ of its territory, in the remaining part of the former Hungary, by 1925, there were about 321000 Hungarian Grey cattle (Bartosiewicz, 1997). In the following years, decline of the breed persisted. The World War II severely disrupted the breeding activity, and many herds were destroyed. Later, during the socialist era, as a result of the rescue programme initiated by Imre Bodó and supported by the Hungarian government (1961), ca. 200 purebred cows and 6 bulls were saved (Bodó et al., 1996). The breeding plan used a special rotational mating scheme of disposable bulls to avoid inbreeding (Bodó, 1990). Breeding activity was highly stimulated by the Association of Hungarian Grey Cattle Breeders, which was founded in 1991. Due to small but permanent subsidies by the state, the Hungarian Grey herds started to increase again. In 2011, the Hungarian Grey population amounted to 7000 cows (Bodó, 2011).

As mentioned in a within-breed investigation (Zsolnai et al., 2014), the Hungarian Grey is considered to belong to the 'Podolic' cattle group (Negrini et al., 2007), named also Podolian or West Ukrainian; however, the origin of its members has been questioned by several authors (Maróti-Agóts, 2011; Manzone, 2011; Filippini, 2011). The genetic origin of the Hungarian Grey cattle has not yet been definitively elucidated. Mitochondrial DNA studies in Hungarian Grey and Italian Grey cattle showed some similarities to other European breeds; in addition, the T1 haplogroup, located phylogeographically in Africa, was not observed in the Hungarian Grey cattle (Maróti-Agóts, 2011; Lancioni et al., 2016).

A few Maremmana bulls were brought to Hungary at the beginning of the 20th century (Bodó, 2011), and the hereditary 1:29 chromosome translocation was introduced by one of them. The abnormality that is linked to embryo losses is absent in purebred Hungarian Grey animals. This rare chromosome disorder was eradicated from the affected herds by investigating more than 800 cattle and culling the carriers of both sexes (Kovács, 1989; Zsolnai et al., 2014).

The objectives of the present paper were to compare the genetic status of Hungarian Grey to other European cattle in the hope to get insight into the history of the breed, like in the case of Maltese (Lancioni et al., 2016), and to initialise molecular trademark development, already performed in Mangalitza pig (Szántó-Egész et al., 2016; Zsolnai et al., 2017), via looking for differences between Hungarian Grey and European cattle breeds.

\section{Material and methods}

\section{Samples}

We used the genomic data (150 K SNP (single nucleotide polymorphism), Geneseek Genotyping BeadChip) of blood samples of 136 Hungarian Grey, 12 Maremmana, 13 Hungarian Fleckvieh and 5 Holstein-Friesian samples and 139 animals from 38 different cattle populations examined using a $770 \mathrm{~K}$ SNP chip dataset (Illumina BovineHD BeadChip, which contains 777692 SNPs) (Upadhyay et al., 2017). Altogether 305 animals were analysed (number of Hungarian Greys was 36 in population studies and 136 in the search of breed-specific alleles). Deoxyribonucleic acid was isolated from samples using a simple protocol (Zsolnai et al., 2003).

Animals for this study were selected by the Association of Hungarian Grey Cattle Breeders to represent all the recorded, paternal lines of the herd. Maremmana samples were provided by the University of Veterinary Medicine Budapest; Fleckvieh and Holstein-Friesian samples were used earlier in other research projects (Anton et al., 2018).

For a detailed comparison of Hungarian Grey to other breeds, nine population were selected; Nelore was an outgroup; choices of Boskarin, Busha, Chianina, Heck, Maltese, Maremmana, Maronesa and Romanian Grey were based on their similar phenotypes and their positions relative to Hungarian Grey after principal component analysis.

\section{Data evaluation}

Data evaluation followed our previous survey (Bâlteanu et al., 2019). A series of quality control procedures was conducted on raw data using SNP \& Variation Suite (SVS) software, v.8.8.1 (Golden Helix, Bozeman, MT, USA): monomorphic markers and unmapped SNPs as well as those with a call rate $<95 \%$ were eliminated from the dataset. In addition, we removed SNPs with a minor allele frequency $<0.05$. Duplicated samples (identical by descent value $>0.95$ ) and individuals with a genotype call rate $<95 \%$ were removed. After filtering, the final dataset included 305 animals and 126150 SNPs. Pairwise genetic distances $\left(F_{\mathrm{ST}}\right)$ of the populations were calculated using SVS software v.8.8.1.

The proportions of mixed ancestry and population structure were evaluated with the ADMIXTURE software v.1.3 (Alexander et al., 2009) using default parameters. ADMIXTURE calculates maximum likelihood estimates of individual ancestries based on the data provided by multiple loci (Alexander et al., 2009). We evaluated different number of clusters ( $K$-value from 2 to 10$)$ by considering the mixed ancestry model. The optimal $K$-value was determined by taking into account the estimates of cross-validation errors (Alexander and Lange, 2011). PLINK software v.1.9 (Purcell et al., 2007) was used to calculate observed $\left(H_{o}\right)$ and expected $\left(H_{e}\right)$ heterozygosities as well as to build a multidimensional scaling plot using a genome-wide identity-by-state pairwise distances matrix (-mds-plot 2 and -cluster options). The - het command of PLINK (Purcell et al., 2007) was used to compute the method-ofmoments relatedness $F$-coefficient.

The detection of ROH (runs of homozygosity) was carried out with PLINK (Purcell et al., 2007). The minimum length of a $\mathrm{ROH}$ was set to $1 \mathrm{Mb}$ in order to minimise the detection of spurious ROH. To make sure that the length of ROH is not affected by low SNP density, the minimum number of SNPs that constituted a ROH was set to 50 considering the calculation method proposed by Lencz et al. (2007):

$$
I=\frac{\log _{\frac{\alpha}{n_{s} \cdot n_{i}}}}{\log _{e}(1-h e t)}
$$


where $n_{s}$ is the number of SNPs per individual, $n_{i}$ is the number of individuals, $\alpha$ is the percentage of false-positive $\mathrm{ROH}$ (set to 0.05 ) and het is the mean SNP heterozygosity across all SNPs. The density of SNPs was set to 1 SNP for each $100 \mathrm{~Kb}$, and a maximum distance of $1000 \mathrm{~Kb}$ was allowed between two consecutive SNPs. The scanning window contained 50 SNPs, and the maximum number of missing SNPs per window was set to five with allowance for one heterozygous SNP.

Each ROH was classified based on its physical length into four size categories: 1 to $\leq 5 \mathrm{Mb}, 5$ to $\leq 15 \mathrm{Mb}, 15$ to $\leq 30 \mathrm{Mb}$, and $>30 \mathrm{Mb}$. For each ROH category, the mean sum of ROH per breed was calculated by summing the lengths of all $\mathrm{ROH}$ in a given individual for each one of the categories under consideration. The inbreeding coefficient derived from $\mathrm{ROH}$ genomic coverage $\left(F_{\mathrm{ROH}}\right)$ was calculated by dividing total $\mathrm{ROH}$ length per individual by total genome length (2715 Mb) for each individual.

For the identification of loci in Hungarian Grey $v$. non-Hungarian Grey comparisons, the names of breeds were recoded to 1 and 0 , respectively. For the correction of population structure, genomic kinship matrix was used in a multilocus mixed model (Segura et al., 2012). The used model was

$$
y=X \beta+Z u+e
$$

where $y$ is the phenotypic value, $X$ is the matrix of fixed effects composed of SNPs and covariates (age and farm), $Z$ is the matrix of random animal effects, e means residual effects, and $\beta$ and $u$ are vectors representing coefficients of fixed and random effects, respectively.

\section{Results}

Analysis of diversity and population structure

On the multidimensional scaling plot, our Maremmana, Hungarian Fleckvieh and Holstein-Friesian samples positioned themselves accordingly to the Maremmana, Fleckvieh and Holstein-Friesian groups originating from a public database
(Upadhyay et al., 2017). Hungarian Grey keeps a wellseparated position from other cattle (Figure 1, Supplementary Figure S1). Descriptive statistics of genetic diversity of Hungarian Grey and the selected nine cattle breeds are shown in Table 1. Observed and expected heterozygosities ranged between 0.353 and 0.502 . While Romanian Grey showed high levels of heterozygosity $\left(H_{o}=0.502, H_{e}=0.373\right)$, Busha showed the lowest level of observed heterozygosities $\left(H_{o}=0.380, H_{e}=0.383\right)$. Hungarian Grey, Maronesa and Romanian Grey have the lowest proportion of the genome covered by ROH $\left(F_{\mathrm{ROH}}\right.$ values are $0.093,0.092$ and 0.061 , respectively). The coefficients of pairwise genetic differentiations (Supplementary Figure S2) are ranging from 0.062 (Hungarian Grey-Maremmana) to 0.492 (Nelore-Maltese). If Nelore is taken out from the comparison, the maximal value is 0.295 (Heck-Maltese). Admixture analyses was performed from $K=2$ to 10 (Supplementary Figure S3); the most probable $K$-value of the selected 10 populations was $K=5$. Data of Upadhyay et al. (2017) have been completed with all Hungarian Grey animals (Figure 2).

Table 1 Diversity statistics of Hungarian Grey cattle and nine other breeds

\begin{tabular}{lcccr}
\hline \hline Breed name & $F_{\mathrm{ROH}}$ & $H_{o}$ & $H_{e}$ & $F$ \\
\hline Boskarin & 0.178 & 0.468 & 0.385 & -0.214 \\
Busha & 0.143 & 0.380 & 0.383 & 0.006 \\
Chianina & 0.135 & 0.476 & 0.395 & -0.206 \\
Heck & 0.269 & 0.402 & 0.370 & -0.087 \\
Hungarian Grey & 0.093 & 0.427 & 0.372 & -0.147 \\
Maltese & 0.306 & 0.416 & 0.353 & -0.178 \\
Maremmana & 0.111 & 0.381 & 0.369 & -0.034 \\
Maronesa & 0.092 & 0.451 & 0.384 & -0.177 \\
Nelore & 0.131 & 0.474 & 0.364 & -0.302 \\
Romanian Grey & 0.061 & 0.502 & 0.373 & -0.345 \\
\hline \hline
\end{tabular}

$F_{\mathrm{ROH}}=$ proportion of the autosomal genome covered by runs of homozygosity $H_{o}=$ observed heterozygosities; $H_{e}=$ expected heterozygosities; $F=$ methodof-moments relatedness coefficient.

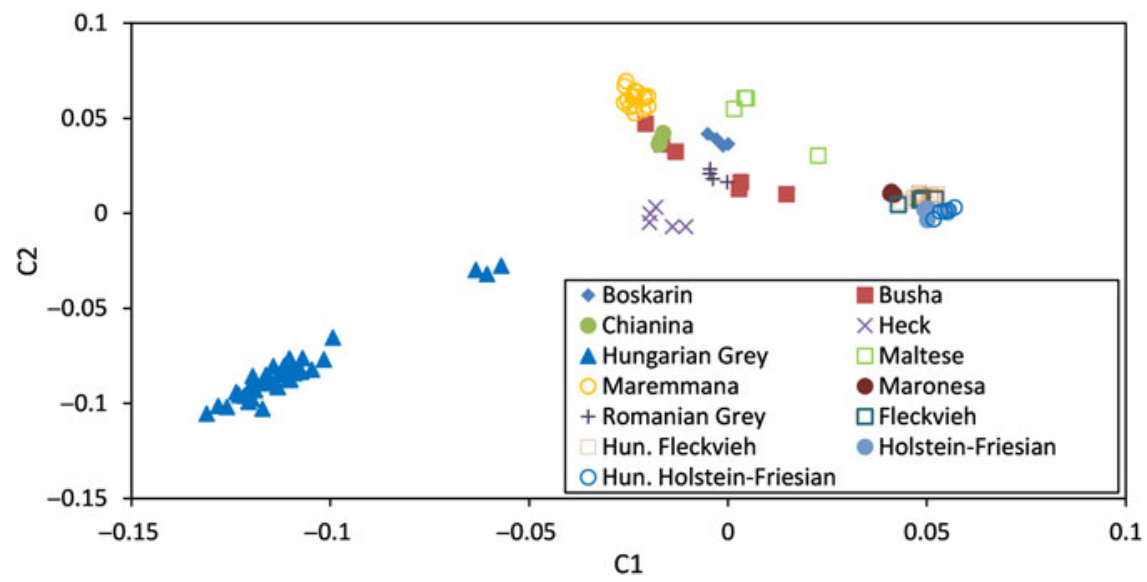

Figure 1 (colour online) Multidimensional scaling plot depicting the relationships between Hungarian Grey and other cattle populations. The following codes are used: $\mathrm{C} 1=$ first component (eigenvalue $=7.681$ ); $\mathrm{C} 2=$ second component (eigenvalue $=2.797$ ) . 

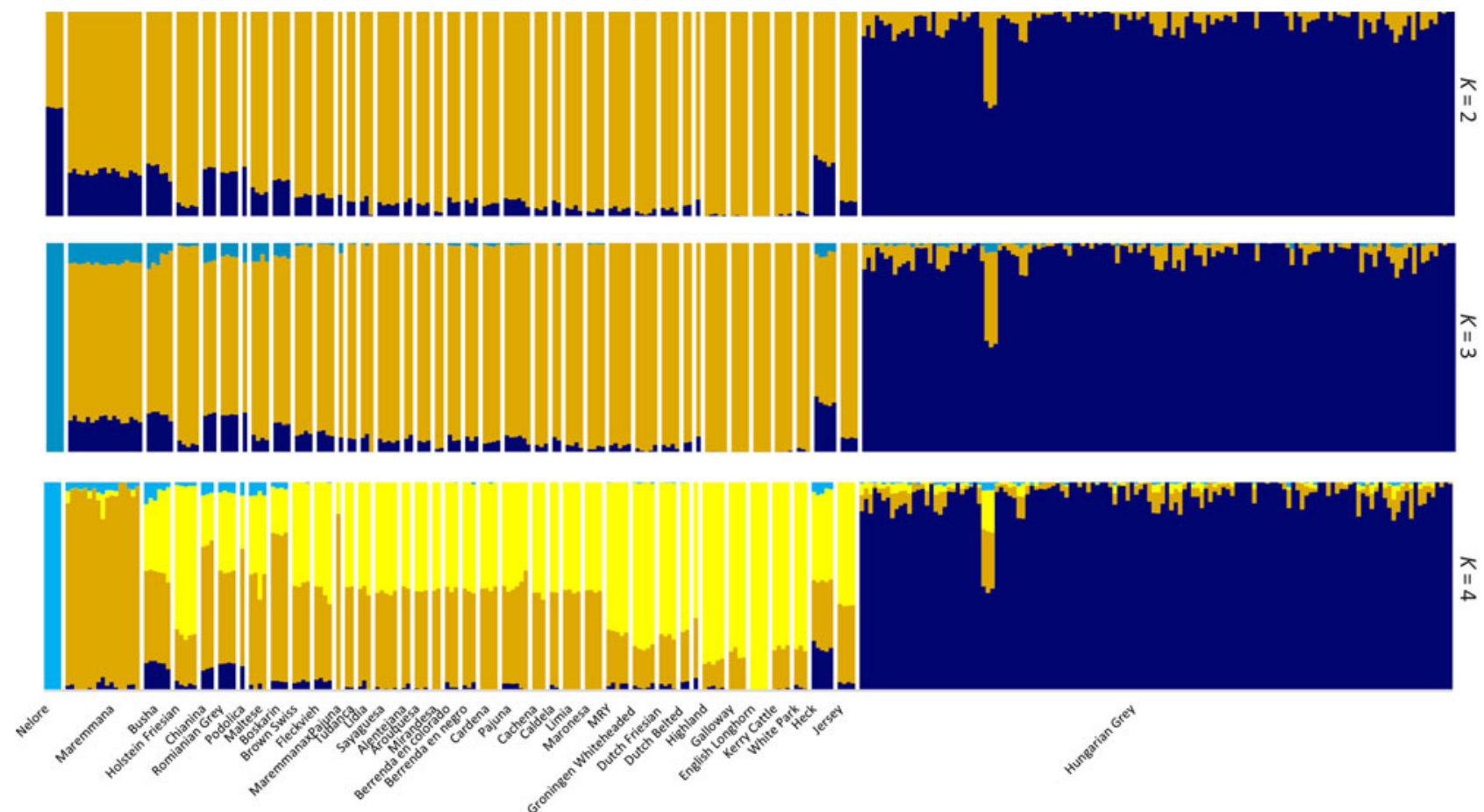

Figure 2 (colour online) Admixture analysis of cattle populations for a range of $K$-values (2 to 4). Each individual is represented by a single column divided into $K$ coloured segments, where $K$ is the number of assumed clusters. Populations are separated by white lines.

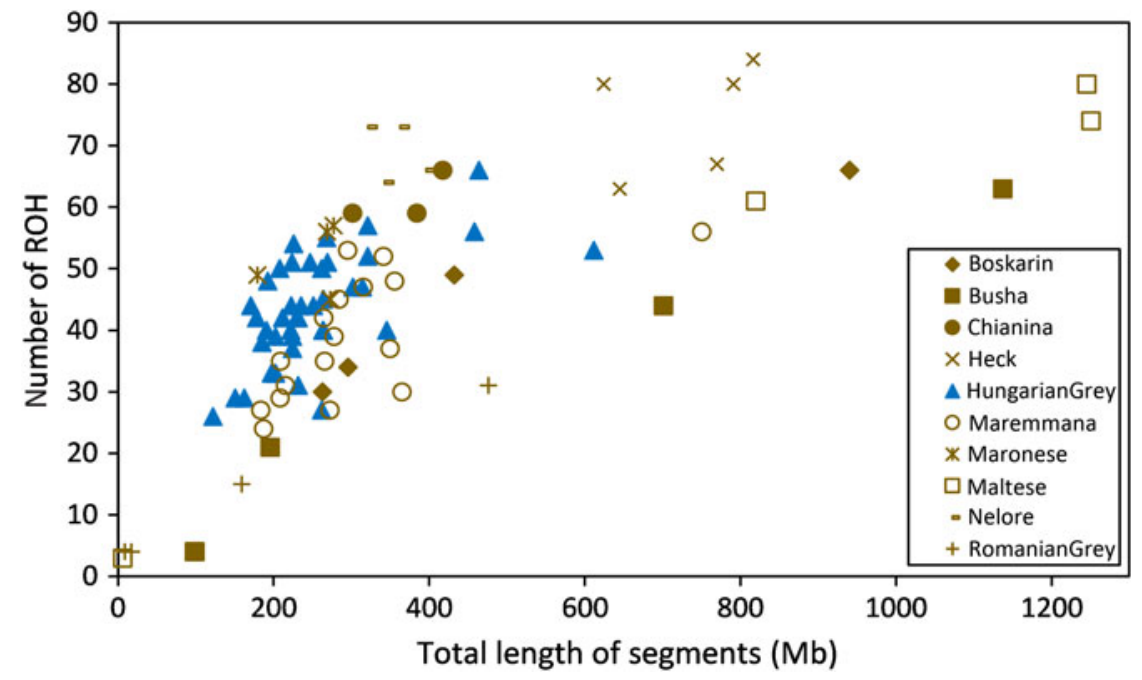

Figure 3 (colour online) Number and total length of runs of homozygosity $(\mathrm{ROH})$ in select European cattle populations. The number of ROH estimated in each individual genome ( $y$-axis) is plotted against total ROH size (i.e. number of megabases covered by ROH in each genome, $x$-axis).

\section{Analysis of runs of homozygosity}

We characterised the length, distribution and frequency of $\mathrm{ROH}$ in 10 cattle populations (Figure 3). The number of $\mathrm{ROH}$ does not show a major departure between the Hungarian Grey cattle and selected breeds with regard to the distribution of individuals according to $\mathrm{ROH}$ number and genomic coverage. Hungarian Grey does not show very long ROH segments $(>700 \mathrm{Mb}$ ) as can be seen in case of Maltese, Heck and Busha individuals. In a comparative analysis of Hungarian Grey (Figure 4), the mean of ROH at medium $\mathrm{ROH}(5$ to $15 \mathrm{Mb}$ ) is above the value of Nelore, Maremmana,
Maronese, Maltese and Romanian Grey. At 15 to $30 \mathrm{Mb}$ $\mathrm{ROH}$ category, Hungarian Grey has the second lowest; at $>30 \mathrm{Mb}$, it has the lowest value. A high level of homozygosity can be observed in Busha, Boskarin and especially Maltese and Heck, reflected also by their $F_{\mathrm{ROH}}$ values (Table 1).

\section{Identification of loci capable of breed differentiation}

During the search for breed-specific loci, we compared the genetic profiles of Hungarian Grey with the available 39 other cattle breeds. We identified 10 candidate breed-specific 
Zsolnai, Maróti-Agóts, Kovács, Bâlteanu, Kaltenecker and Anton

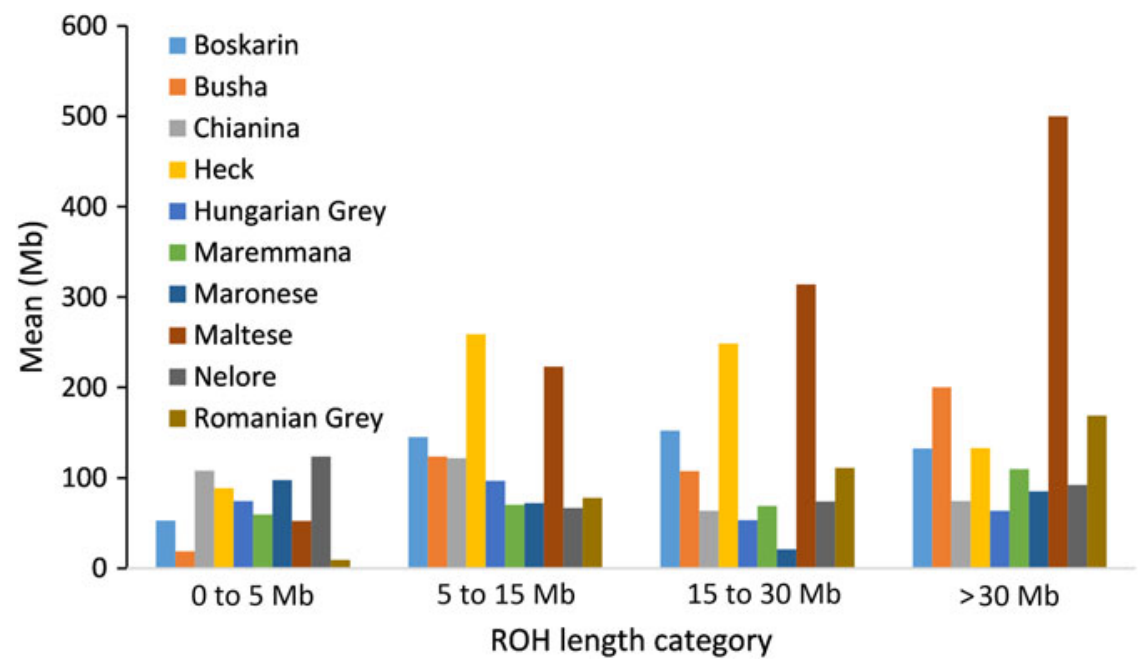

Figure 4 (colour online) Classification of runs of homozygosity (ROH) identified in select cattle populations based on their size ( $x$-axis) and mean sum of ROH (y-axis, measured in megabases) within each $\mathrm{ROH}$ category and averaged per breed.

Table 2 List of breed-specific loci and genomic location of Hungarian Grey

\begin{tabular}{lcrc}
\hline \hline $\begin{array}{l}\text { Marker identification } \\
\text { number }\end{array}$ & $\begin{array}{c}\text { Position on } \\
\text { chromosomes }\end{array}$ & $-\log _{10} P$ & FDR \\
\hline rs133006329 & $6: 18433887$ & 7.41 & $1.5 \mathrm{e}-03$ \\
rs133483745 & $6: 62216762$ & 7.22 & $1.0 \mathrm{e}-03$ \\
rs134638117 & $14: 41738359$ & 7.23 & $2.0 \mathrm{e}-03$ \\
rs110270638 & $14: 46501195$ & 5.73 & $2.7 \mathrm{e}-02$ \\
rs110805877 & $15: 34171356$ & 5.66 & $2.8 \mathrm{e}-02$ \\
rs42998213 & $16: 70234170$ & 8.45 & $2.0 \mathrm{e}-04$ \\
rs43349802 & $20: 4660259$ & 18.96 & $1.3 \mathrm{e}-14$ \\
rs135917971 & $20: 9755101$ & 7.13 & $1.0 \mathrm{e}-03$ \\
rs108965238 & $20: 24831468$ & 5.13 & $8.5 \mathrm{e}-02$ \\
rs110526432 & $24: 42725919$ & 7.18 & $1.0 \mathrm{e}-03$ \\
\hline \hline
\end{tabular}

FDR $=$ false discovery rate.

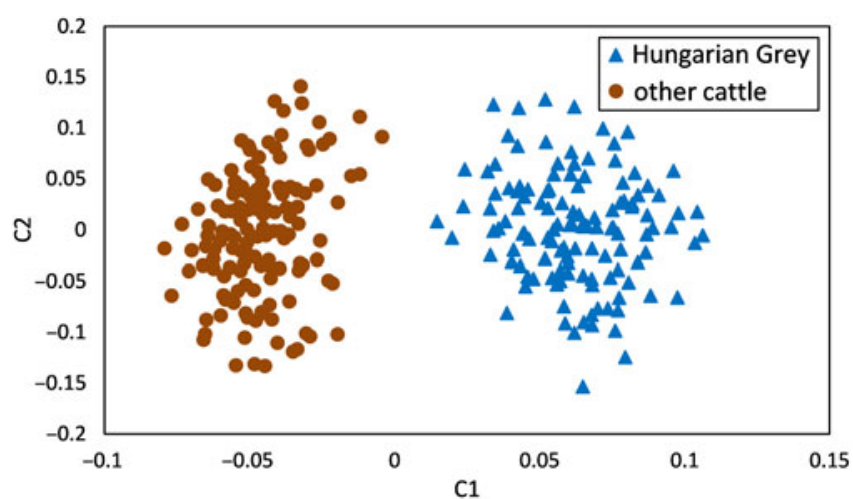

Figure 5 (colour online) Multidimensional scaling plot of Hungarian Grey and European cattle populations. The following codes are used: $\mathrm{C} 1=$ first component (eigenvalue $=95.423$ ); C2 $=$ second component (eigenvalue $=14.286$ )

markers $\left(-\log _{10} P>5\right)$ on chromosomes $6,14,15,16$, 20 and 24 (Table 2). Using these 10 loci, a multidimensional scaling plot gives two distinct groups (Figure 5): Hungarian Grey and non-Hungarian Grey animals. On chromosome 20, the highest $-\log _{10} P$ value (18.96) is far above the value of other SNP hits.

On chromosome 20, rs43349802, an intronic variant of ATP6VOE1 (ATPase $\mathrm{H}+$ Transporting V0 Subunit E1) gene responsible for adiposity, obesity and skeletal muscle development in humans and in mouse, is among the candidate genes associated with mid-test metabolic weight in Hereford and Simmental $\times$ Angus cattle (Seabury et al., 2017). ATP6VOE1 is the top positive hubbing gene for oleic acid content in Nelore cattle (Oliveira et al., 2019). Upon investigating transcription during sepsis, ATP6VOE1 was among the differentially expressed genes (Zhang et al., 2017) in three enriched KEGG pathways, such as oxidative phosphorylation, phagosome and epithelial cell signalling in Helicobacter pylori infection.

\section{Discussion}

Based on a principal component analysis of mtDNA, among the 18 podolian cattle breeds, two main groups were found (Di Lorenzo et al., 2018), where Maremmana and Chianina belonged to a six-member group, while Slavonian Syrmian, Istrian cattle, Piemontese, Katerini, Calvana, Bianca di Val Padana, Podolsko, Mucco Pisano, Ukrainian, Bulgarian, Hungarian and Romanian Grey were in the other group. However, Hungarian Grey was markedly positioned as a separated breed from the above-listed 11 breeds. In our multidimensional scaling analysis of SNP data, the Hungarian Grey animals also represent a distinct group among the selected cattle (Figure 1) and among the whole dataset (Supplementary Figure S1) of Upadhyay et al. (2017). The three Hungarian Grey animals, outstanding from the main group of that breed, are known as animals with Maremmana ancestry according to their pedigree.

The coefficients of genetic differentiation $\left(F_{S T}\right)$ show that the closest, but moderately differentiated, group to Hungarian Grey are Maremmana $\left(F_{\mathrm{ST}}=0.086\right)$ and Busha 
Genome-wide evaluation of the Hungarian Grey cattle

$\left(F_{\mathrm{ST}}=0.067\right)$. The latter is known to have Hungarian Grey influence (van Vuure, 2005). The remaining seven breeds display a large genetic differentiation from Hungarian Grey $\left(F_{\mathrm{ST}}>0.100\right)$.

Population structure analyses provide evidence of a composite origin of Busha, Chianina and Maronese cattle (Supplementary Figure S3; $5 \leq K \leq 7$ ). At $K$ values $>7$, Hungarian Grey samples started to split into two subclusters, which required further investigation in the herdbook. The three Hungarian Grey animals - displaying Maremmana influence at $K$-value $>3$ - have recorded Maremmana ancestry in the herdbook. The Maremmana ancestry of these animals was also detected by an analysis of 18 microsatellites using over 15000 Hungarian Grey and 32 Maremmana samples where $<1 \%$ of Hungarian Greys had been proved to have Maremmana ancestry (unpublished data).

On the reproduced figure of Upadhyay et al. (2017), Nelore represents a distinct group (at $K=4$ ). Breeds from the database show similar admixture as reported by Upadhyay et al. (2017), while Hungarian Grey remains in distinct cluster (Figure 2) in agreement with the amplified fragment length polymorphism analysis of Negrini et al., (2007). A mixed origin of Heck, Busha and several other breeds can be noticed, as well as a low portion of mixing between Hungarian Grey and other breeds (excluding Nelore), especially in Maremmana, Busha, Chianina, Romanian Grey and Heck. We noticed reciprocal colours in Hungarian Grey and other European cattle; ocher and yellow portions in Hungarian Grey individuals; and dark blue portions in other European cattle. Such mixing events might have happened via official trading of individuals or during the movement of animal masses in the 16th century when thousands of Hungarian Greys were driven on foot to German fairs and Italy (Strassburg, Augsburg, Nürnberg and Venice) (Miskulin, 1905; Takáts,1927).

An analysis of homozygosity runs revealed that long ROH segments cannot be found in Hungarian Grey (Figure 3), and the mean $\mathrm{ROH}$ at 15 to $30 \mathrm{Mb}$ and at $>30 \mathrm{Mb}$ was low (Figure 4), indicating a successful avoidance of inbreeding during the implementation of herdbook-based mating plans (Bodó et al., 1996).

SNPs performing well in differentiating Hungarian Greys from other breeds (Figure 5) are the base of developing molecular trademark (Szántó-Egész et al., 2016; Zsolnai et al., 2017) for the beef produced by Hungarian Grey breeders. Similar achievements have been described in cattle such as the inclusion of seven breeds into the quest for breed-specific SNPs (Czech et al., 2018); testing of different identification methods of a small, cost-effective set of SNPs for breed assignment (Kumar et al., 2019); or finding trait-associated loci (Mastrangelo et al., 2016). Our results also demonstrate that Hungarian Grey animals form a distinct group, markedly distinguishable from other European cattle. However, origins of the breed still remain unrevealed; so, further investigation is needed contrasting the samples with Turkish and other eastward-located breeds to follow up the hypothesis of the Turkish migration route of Hungarian Grey.

\section{Acknowledgements}

Financial support no. 214/C 1635329838 from the Hungarian Ministry of Agriculture is gratefully acknowledged.

(1) A. Zsolnai 0000-0002-8382-1503

\section{Declaration of interest}

The authors declare that they have no competing interests.

\section{Ethics statement}

Sampling was performed by trained veterinarians following standard procedures and relevant national guidelines to ensure appropriate animal care.

\section{Software and data repository resources}

Data were deposited at the headquarters of the Association of Hungarian Grey Cattle Breeders. Access to the data is confidential.

\section{Supplementary material}

To view supplementary material for this article, please visit https://doi.org/10.1017/S1751731120000634

\section{References}

Alexander DH and Lange K 2011. Enhancements to the ADMIXTURE algorithm for individual ancestry estimation. BMC Bioinformatics 12, 246.

Alexander DH, Novembre J and Lange K 2009. Fast model-based estimation of ancestry in unrelated individuals. Genome Research 19, 1655-1664.

Anton I, Húth B, Füller I, Gábor G, Holló G and Zsolnai A 2018. Effect of singlenucleotide polymorphisms on the breeding value of fertility and breeding value of beef in Hungarian Simmental cattle. Acta Veterinaria Hungarica 66, 215-225.

Bâlteanu VA, Cardoso TF, Amills M, Egerszegi I, Anton I, Beja-Pereira A and Zsolnai A 2019. The footprint of recent and strong demographic decline in the genomes of Mangalitza pigs. Animal 13, 2440-2446.

Bartosiewicz L 1996. Hungarian Grey cattle: in search of origins. Hungarian Agricultural Research 5, 4-9.

Bartosiewicz L 1997. The Hungarian Grey cattle: a traditional European breed. Animal Genetic Resources Information 21, 49-60.

Bodó I 1990. The maintenance of Hungarian breeds of farm animals threatened by extinction. In Genetic conservation of domestic livestock (ed. L Alderson), pp. 73-84. CABI publishing, Wallingford, UK.

Bodó I, Gera I and Koppány G 1996. The Hungarian Grey cattle breed. Association of the Hungarian Grey Cattle Breeders, Budapest, Hungary. Bodó I 2011. Podolic cattle. Debrecen University, Debrecen, Hungary.

Czech B, Frąszczak M, Mielczarek M and Szyda J 2018. Identification and annotation of breed-specific single nucleotide polymorphisms in Bos taurus genomes. PLOS ONE 13, e0198419.

Di Lorenzo P, Lancioni H, Ceccobelli S, Colli L, Cardinali I, Karsli T, Capodiferro MR, Sahin E, Ferretti L, Marsan PA, Sarti FM, Lasagna E, Panella F and Achilli A 2018. Mitochondrial DNA variants of Podolian cattle breeds testify for a dual maternal origin. PLoS ONE 13, e0192567.

Filippini F 2011. Probable origin and history of Podolic breeds in Italy. In Podolic cattle (ed. I Bodó), pp. 19-21. Debrecen University, Debrecen, Hungary.

Kovács A 1989. Application of cytogenetics to cattle breeding improvement. In Cytogenetics of animals (ed. CRE Halnan), pp. 221-234. CABI Publishing, Wallingford, UK.

Kumar H, Panigrahi M, Chhotaray S, Parida S, Chauhan A, Bhushan B, Gaur GK, Mishra BP and Singh RK 2019. Comparative analysis of five different methods to design a breed-specific SNP panel for cattle. Animal Biotechnology, https://doi. org/10.1080/10495398.2019.1646266, Published online by Tailor and Francis Online 31 July 2019. 
Lancioni H, Di Lorenzo P, Cardinali I, Ceccobelli S, Capodiferro MR, Fichera A Viola Grugni V, Semino 0, Ferretti L, Gruppetta A, Attard G, Achilli A and Lasagna E 2016. Survey of uniparental genetic markers in the Maltese cattle breed reveals a significant founder effect but does not indicate local domestication. Animal Genetics 47, 267-269.

Lencz T, Lambert C, DeRosse P, Burdick KE, Morgan TV, Kane JM, Kucherlapati R and Malhotra AK 2007. Runs of homozygosity reveal highly penetrant recessive loci in schizophrenia. Proceedings of the National Academy of Sciences of the United States of America 104, 19942-19947.

Manzone M 2011. Improperly naming of an Italian breed. In Podolic cattle (ed. I Bodó), pp. 17-18. Debrecen University, Debrecen, Hungary.

Maróti-Agóts Á 2011. The origin of Podolic breeds and the name of the breed group. In Podolic cattle (ed. I Bodó), pp. 11-17. Debrecen University, Debrecen, Hungary.

Mastrangelo S, Tolone M, Gerlando RD, Fontanesi L, Sardina MT and Portolano B 2016. Genomic inbreeding estimation in small populations: evaluation of runs of homozygosity in three local dairy cattle breeds. Animal 10, 746-754.

Mattesz J 1927. A mezőhegyesi magyarfajta marha monográfiája (The monography of Hungarian cattles in Mezőhegyes). Székely és Társa Könyvnyomdája, Sopron, Hungary.

Miskulin A 1905. Magyar múvelődéstörténeti mozzanatok Giovanni és Matteo Villani krónikái alapján (Hungarian cultural history based on the chronicles of Giovanni and Matteo Villani). Stephaneum, Budapest, Hungary.

Negrini R, Nijman IJ, Milanesi E, Moazami-Goudarzi K, Williams JL, Erhardt G, Dunner S, Rodellar C, Valentini A, Bradley DG, Olsaker I, Kantanen J, Ajmone-Marsan $P$, Lenstra JA and European Cattle Genetic Diversity Consortium 2007. Differentiation of European cattle by AFLP fingerprinting. Animal Genetics 38, 60-66.

Oliveira PSN, Coutinho LL, Cesar ASM, Silva Diniz WJ, de Souza MM, Andrade BG, Koltes JE, Mourão GB, Zerlotini A, Reecy JM and Regitano LCA 2019. Co-expression networks reveal potential regulatory roles of miRNAs in fatty acid composition of Nelore cattle. Frontiers in Genetics 10, 651.

Purcell S, Neale B, Todd-Brown K, Thomas L, Ferreira MAR, Bender D, Maller J, Sklar P, de Bakker PIW, Daly MJ and Sham PC 2007. PLINK: a tool set for wholegenome association and population-based linkage analyses. American Journal of Human Genetics 81, 559-575.
Seabury CM, Oldeschulte DL, Saatchi M, Beever JE, Decker JE, Halley YA Bhattarai EK, Molaei M, Freetly HC, Hansen SL, Yampara-Iquise $\mathrm{H}$, Johnson KA, Kerley MS, Kim JW, Loy DD, Marques E, Neibergs HL, Schnabel RD Shike DW, Spangler ML, Weaber RL, Garrick DJ and Taylor JF 2017. Genomewide association study for feed efficiency and growth traits in U.S. Beef cattle. BMC Genomics 18, 386

Segura V, Vilhjálmsson BJ, Platt A, Korte A, Seren Ü, Long Q and Nordborg M 2012. An efficient multi-locus mixed-model approach for genome-wide association studies in structured populations. Nature Genetics 44, 825-830.

Szántó-Egész $R$, Jánosi $A$, Mohr A, Szalai G, Koppányné Szabó E, Micsinai $A$, Sipos R, Rátky J, Anton I and Zsolnai A 2016. Breed-specific detection of Mangalica meat in food products. Food Analytical Methods 9, 889-894.

Takáts S 1927. Szegény magyarok (poor Hungarians). Genius, Budapest, Hungary. Tormay B 1901. A szarvasmarha és tenyésztése I-II (The cattle and cattle breeding). Athenaeum Irodalmi és Nyomdai R.T., Budapest, Hungary.

Upadhyay MR, Chen W, Lenstra JA, Goderie CRJ, MacHugh DE, Park SDE, Magee DA, Matassino D, Ciani F, Megens H-J, van Arendonk JAM, Groenen MAM, European Cattle Genetic Diversity Consortium and Crooijmans RPMA 2017. Genetic origin, admixture and population history of aurochs (Bos primigenius) and primitive European cattle. Heredity 118, 169-176.

van Vuure C 2005. Retracing the Aurochs: history, morphology and ecology of an extinct wild Ox. Pensoft Publishing, Sofia, Bulgaria.

Zhang J, Cheng Y, Duan M, Qi N and Liu J 2017. Unveiling differentially expressed genes upon regulation of transcription factors in sepsis. 3Biotech 7, 46. https://doi.org/10.1007/s13205-017-0713-x, Published online by Springer Link 25 April 2017.

Zsolnai A, Anton I, Kühn C and Fésüs L 2003. Detection of single-nucleotide polymorphisms coding for three ovine prion protein variants by primer extension assay and capillary electrophoresis. Electrophoresis 24, 634-638.

Zsolnai A, Kovács A, Anton I, Rátky J, Brüssow KP, Józsa C, Bán B and Gyurmán A 2014. Comparison of different Hungarian Grey herds as based on microsatellite analysis. Animal Science Papers and Reports 32, 121-130.

Zsolnai $A$, Szántó-Egész $R$, Ferencz-Elblinger $E$, Dang Huu $A$, Jánosi $A$, Koppányné Szabó E and Anton I 2017. Loop-Mediated Isotherma Amplification based approach as an alternative to Recombinase Polymerase Amplification based detection of Mangalitza component in food products. Acta Alimentaria 46, 384-389. 